\title{
The Effect of Cocopeat and Charcoal Combination in Growing Media of Green Mustard (Brassica rapa L.) Var. Parachinensis Growth
}

\author{
Masniar Vina Kesti*, Bambang Irawan, Priyambodo, Martha L. Lande \\ Jurusan Biologi, Fakultas Matematika dan IImu Pengetahuan Alam, Universitas Lampung \\ Jalan Prof. Dr. Soemantri Brodjonegoro No. 1 Bandar lampung, Lampung 35145 \\ *Email: vinaakesti@gmail.com
}

\begin{abstract}
Green mustard is one type of vegetable that is easily cultivated and has good prospects to increase farmers' income and community nutrition. Growing media is a material that is useful as a place to stand upright seedlings, to develop seedling roots, to store water, gas, and nutrients needed for seedling growth. The purpose of this study is a). to determine the effect of using a combination of cocopeat and charcoal as a medium for planting mustard greens, b). to get the best dosage of the composition of the growing medium on the growth of mustard greens. The study was conducted in a completely randomized design (CRD) with 4 treatments and 6 replications. The data were analyzed by analysis of variance (ANOVA) and further tested with the Least Significant Difference test $(\mathrm{LSD})=5 \%$. The results showed that the use of cocopeat growing media and charcoal influenced germination and vigor index. Cocopeat and charcoal have a significant effect on fresh and dry weight and chlorophyll content of mustard greens. The mixture of cocopeat growing media and charcoal on P1 did not affect the growth of green mustard on the dry weight. Fresh weight gave a significant effect on $\mathrm{K} 1$ and P1 was also significantly different from P2 and P3.
\end{abstract}

Keywords: growing media, soil, charcoal, cocopeat, green mustard

\section{PENDAHULUAN}

Sawi hijau merupakan salah satu jenis sayuran daun yang mudah dibudidayakan, dan memiliki prospek yang baik dalam upaya meningkatkan pendapatan petani dan gizi masyarakat. Hal tersebut dikarenakan Indonesia memiliki kondisi wilayah yang sangat cocok untuk komoditas tersebut (Rahman dan Lisa, 2008).

Sayuran merupakan salah satu makanan yang wajib untuk dikonsumsi oleh semua kalangan, mulai dari balita hingga lansia, karena sayuran banyak mengandung vitamin yang dibutuhkan oleh tubuh manusia. Salah satu sayuran yang sering dibudidayakan adalah sayuran sawi. Sawi hijau merupakan tanaman dari Familia rassicaceae yang bernilai ekonomis terutama sebagai sumber sayuran (Setyorini dan Sulaeman, 2003).

Pertumbuhan tanaman dipengaruhi oleh dua faktor, yaitu faktor eksternal dan faktor internal. faktor eksternal yang memberikan pengaruh strategis bagi pertumbuhan semai, Faktor internal meliputi air dan mineral, cahaya, jarak antar polybag, volume penyiraman dan lain sebagainya. Media tanam merupakan suatu bahan yang berguna sebagai tempat untuk berdiri tegaknya semai, sebagai tempat untuk berkembang akar semai, sebagai tempat untuk menyimpan air, gas dan zat hara yang diperlukan untuk pertumbuhan semai (Indriyanto, 2013).

Salah satu bahan organik yang dapat digunakan sebagai media tumbuhan adalah limbah sabut kelapa, olahan sabut kelapa yang digunakan sebagai media tanam semai disebut dengan cocopeat. Cocopeat merupakan salah satu media tanam yang dihasilkan dari proses penghancuran sabut kelapa, proses penghancuran sabut dihasilkan serat atau fiber, serta serbuk halus atau cocopeat (Hidayah dan Irawan, 2012). 
Kelebihan cocopeat sebagai media tanam dikarenakan karakteristiknya yang mampu mengikat dan menyimpan air dengan kuat, serta mengandung unsur-unsur hara esensial, seperti kalsium (Ca), magnesium $(\mathrm{Mg})$, kalium $(\mathrm{K})$, natrium $(\mathrm{N})$, dan fosfor $(\mathrm{P})$ (Muliawan, 2009).

Selain cocopeat bahan lain yang bisa digunakan sebagai media tanam adalah arang sekam salah satu bahan organik yang dapat dijadikan bahan baku pembuatan alat aplikasi irigasi bawah permukaan tanah (subsurface irrigation). Arang sekam padi memiliki sifat poros sehingga dapat meloloskan air dengan baik. Kandungan silika cukup tinggi yang terkandung dalam arang sekam padi yaitu $\pm 67,30 \%$ membuat arang sekam padi sulit untuk mengalami proses dekomposisi (Oyetola dan Abdullahi, 2006).

\section{METODE}

Penelitian ini dilaksanakan di Laboratorium Botani, Jurusan Biologi, Fakultas Matematika dan Ilmu Pengetahuan Alam, Universitas Lampung dari bulan Juli sampai Agustus 2019.

Penelitian ini dilakukan dalam Rancangan Acak Lengkap (RAL), dengan faktor utama adalah berbagai kombinasi arang sekam dan cocopeat. Jumlah perlakuan 4 dengan masing masing 6 ulangan sehingga jumlah satuan percobaan adalah 24. Parameter yang diamati adalah daya berkecambah, indeks vigor, berat segar, berat kering dan kadar klorofil. Data yang diperoleh dianalisis menggunakan Analisis Ragam (ANARA) dan dilakukan uji lanjut BNT (Beda Nyata Terkecil) pada taraf 5\%.

\section{HASIL DAN PEMBAHASAN}

\section{Daya berkecambah}

Pada uji daya berkecambah menggunakan uji regresi linier menunjukkan bahwa grafik uji daya berkecambah pada hari ke-1 sampai hari ke-7 pertumbuhan yang didapat mengalami peningkatan pertumbuhan yang signifikan disebabkan semakin bertambahnya umur maka semakin banyak benih yang berkecambah maka disebut juga sebagai linier positif (Gambar 1).

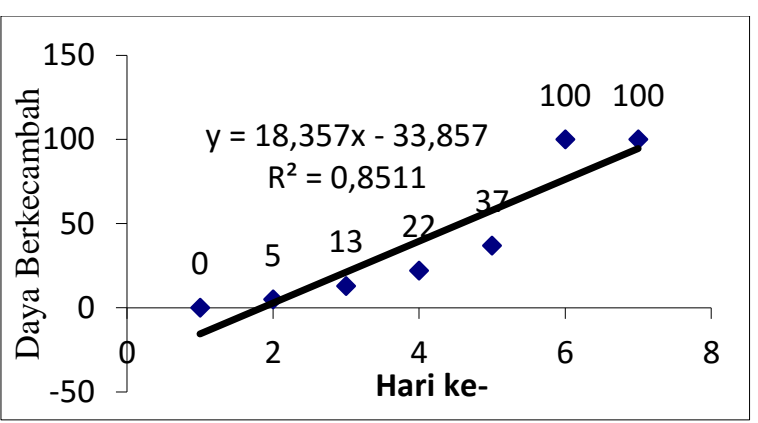

Gambar 1. Laju daya berkecambah tanaman sawi hijau dari hari ke-1 hingga ke-7

Kemampuan daya berkecambah pada tanaman sawi meningkat sejalan dengan peningkatan hari (Gambar 1). Kemampuan daya berkecambah pada hari ke-6 lebih tinggi dibandingkan dengan hari ke-1, kemampuan daya berkecambah pada hari ke-7 lebih meningkat dibandingkan dengan hari ke-1. Hal ini dilihat dari pengamatan benih yang hidup atau mati. Suatu benih dikatakan tumbuh normal bila perkecambahan benih tersebut menunjukkan kemampuan untuk tumbuh dan berkembang menjadi bibit tanaman yang baik dan normal pada lingkungan yang telah disediakan yang sesuai dengan kepentingan pertumbuhan tumbuhan dan perkembangan tanaman tersebut.

Perkecambahan dapat diartikan dimulainya proses pertumbuhan embrio dari benih yang sudah matang. Uji daya berkecambah dilakukan untuk mengetahui potensi benih yang dapat berkecambah dari suatu kelompok atau satuan berat benih (Mulyana dan Asmarahman, 2012).

\section{Indeks Vigor}

Berdasarkan uji regresi linier pada grafik dibawah bahwa selama benih yang

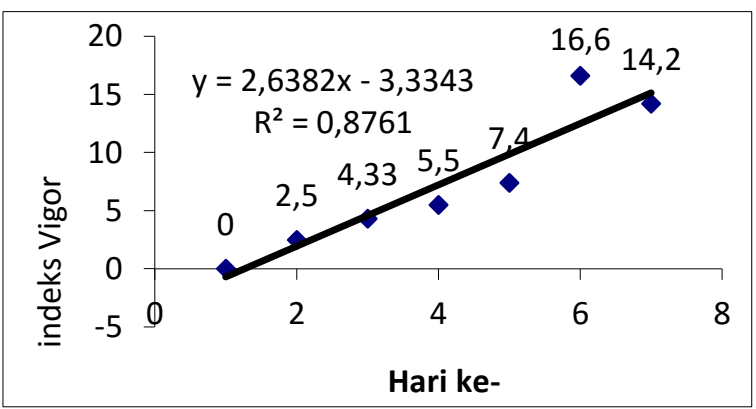

Gambar 2. Laju indeks vigor tanaman sawi hijau dari hari ke-1 hingga ke-7 
dikecambahkan selama 7 hari mendapatkan jumlah benih yang berbeda-beda hal ini disebabkan faktor lingkungan yang mempengaruhi jumlah benih yang berkecambah setiap hari nya. Berikut grafik regresi linier indeks vigor dibawah ini (Gambar 2).

Kemampuan indeks vigor juga pada tanaman sawi meningkat dari hari ke dari hari ke-1 hingga ke-7 (Gambar 2). Pada uji indeks vigor pada hari ke-1 menunjukkan belum terdapat peningkatan jumlah benih yang berkecambah, namun pada hari ke-7 mengalami peningkatan jumlah benih yang berkecambah sebanyak benih yang di kecambahkan.

Berdasarkan data pada Gambar 2. diatas indeks vigor tanaman sawi hijau mengalami peningkatan daya dan kecepatan daya berkecambahnya tinggi. Indeks vigor merupakan sebagai sekumpulan sifat yang dimiliki benih yang menentukan tingkat potensi aktifitas dan kinerja benih atau lot benih selama perkecambahan dan munculnya kecambah (ISTA, 2006).

\section{Jumlah daun}

Data pengamatan jumlah daun pada tanaman sawi hijau dari minggu pertama penyemaian sampai minggu terakhir penanaman (Gambar 3). Pada penyemaian minggu pertama jumlah daun sawi hijau yaitu 2 helai daun, pada minggu ke-dua setelah penanaman di polybag daun sawi hijau tumbuh menjadi 3 helai daun pada media tanam K1, P1, P2, P3.

Pada minggu ke-tiga setelah penanaman daun sawi bertambah menjadi $5-6$ helai daun, pada K1 jumlah daun lebih banyak tumbuh dibandingkan dengan media tanam P1, P2 dan P3, pada minggu terakhir P2 dan P3 jumlah daun yang bertambah hanya 2 helai daun tanaman sawi hijau.

Dilihat dari pengamatan jumlah daun secara visual, semua tanaman yang menggunakan arang sekam dan cocopeat terlihat tumbuh normal dengan ciri-ciri daun lebih luas dan lebih banyak. Sedangkan, ciri daun yang diamati dari perlakuan kontrol adalah daun lebih tebal, sempit dan terlihat kaku. Penanaman jumlah daun tanaman sawi hijau bertambah menjadi $10-13$ helai pada $\mathrm{K} 1$.

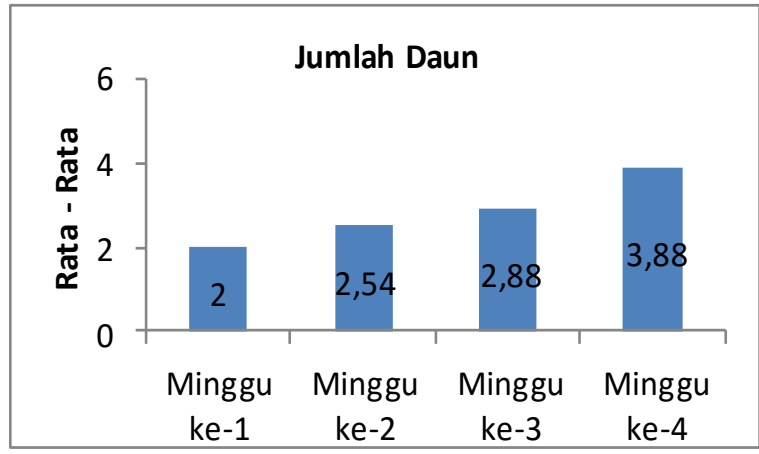

Gambar 3. Rata-rata Jumlah Daun Minggu ke-1 sampai ke Minggu ke-4.

Menurut Wijaya (2008), keadaan tanaman dengan ciri daun lebih luas menandakan tersedianya nitrogen pada media tumbuh, sedangkan tanaman yang mengalami kekurangan nitrogen. Menurut Sarief (1985), akan mengakibatkan tebalnya dinding sel daun dengan ukuran sel yang kecil, dengan demikian daun menjadi keras penuh dengan serat-serat. Nitrogen berperan dalam pembentukan asam amino yang mempunyai multi fungsi didalam metabolism tanaman. Nitrogen tersedia bebas di alam dalam bentuk $\mathrm{N}_{2}$ tetapi tanpa bantuan mikroba penambat nitrogen tumbuhan tidak dapat menggunakannya

(Campbell et al, 2003).

\section{Berat Segar}

Pengamatan bobot segar tanaman dilakukan dengan cara menimbang keseluruhan tanaman meliputi akar, batang, dan daun. Satuan pengukuran adalah gram. (Tabel 1). Berdasarkan uji BNT 5\% perlakuan $\mathrm{K}$ (kontrol) tidak berbeda nyata dengan P1 akan tetapi berbeda nyata dengan perlakuan P2 dan P3.

Pada tabel 1, menunjukan bahwa perlakuan $\mathrm{K}$ (kontrol) tidak berbeda nyata dengan semua perlakuan, karena masing masing perlakuan memiliki nilai yang sama tinggi di setiap perlakuan. Pemberian kombinasi arang sekam dengan cocopeat juga dapat membantu meningkatkan daya ikat air pada organo-karbon sehingga tanaman akan tercukupi ketersediaan air. Proses pembentukan dan perkembangan organ tanaman sangat dipengaruhi oleh ketersediaan air di dalam tanah. 
Pembentukan dan perkembangan organ tanaman (daun, akar, dan batang) berhubungan dengan proses sel tanaman untuk membesar.

Tabel 1. Rata rata berat segar total tanaman sawi hijau

\begin{tabular}{lc}
\hline Perlakuan & Berat segar $(\mathrm{gr}) \pm$ SetDv \\
\hline K & $69,490 \pm 25,9280^{\mathrm{a}}$ \\
P1 & $73,600 \pm 9,7200^{\mathrm{a}}$ \\
P2 & $57,548 \pm 11,3515^{\mathrm{b}}$ \\
P3 & $62,525 \pm 11,3795^{\mathrm{b}}$ \\
\hline
\end{tabular}

Keterangan: K1(kontrol) : Tanah, P1 : Arang Sekam 50\% + Tanah $25 \%$ +Cocopeat 25\%, P2 : Arang Sekam 25\% +Tanah $25 \%+$ Cocopeat $50 \%$, P3 : Arang Sekam $25 \%+$ Tanah $50 \%+$ Cocopeat $25 \%$.

\section{Berat Kering}

Berat kering merupakan akumulasi dari berbagai cadangan makanan seperti protein, karbohidrat, dan lipida (lemak) serta akumulasi fotosintat yang berada dibatang dan daun. Berikut data rata rata berat kering tanaman sawi pada Tabel 2.

Tabel 2. Rata-rata berat kering total tanaman sawi hijau

\begin{tabular}{cl}
\hline Perlakuan & $\begin{array}{l}\text { Berat kering (gr) } \pm \\
\text { SetDv }\end{array}$ \\
\hline K & $0,666 \pm 0,2187^{\mathrm{a}}$ \\
P1 & $0,408 \pm 0,1560^{\mathrm{b}}$ \\
P2 & $0,605 \pm 0,2179^{\mathrm{ab}}$ \\
P3 & $0,733 \pm 0,1273^{\mathrm{a}}$ \\
\hline
\end{tabular}

Keterangan: K1(kontrol) : Tanah, P1 : Arang Sekam 50\% + Tanah $25 \%$ +Cocopeat 25\%, P2 : Arang Sekam 25\% +Tanah $25 \%+$ Cocopeat $50 \%$, P3 : Arang Sekam $25 \%+$ Tanah $50 \%+$ Cocopeat $25 \%$.

Berdasarkan uji BNT taraf $5 \%$ pada perlakuan $\mathrm{K}$ (kontrol) tidak berbeda nyata dengan P2 dan P3 akan tetapi berbeda nyata dengan perlakuan $\mathrm{P} 1$. Hasil rerata berat kering pada tabel $1.2 \mathrm{di}$ atas menunjukkan bahwa perlakuan $\mathrm{K}$ (kontrol) tidak berbeda nyata dengan perlakuan lainnya, namun memiliki nilai yang berbeda pada setiap perlakuannya.

Berat kering tanaman dipengaruhi oleh perkembangan daun dan intensitas matahari, tanaman yang memiliki daun yang lebih luas dapat menyerap sinar matahari dengan efektif, sehingga dapat menghasilkan fotosintat lebih banyak karena dapat melakukan fotosintesis dengan baik. Selama pertumbuhan, tanaman mengalami fotosintesis dan berat kering merupakan biomassa tanaman yang merupakan hasil akumulasi fotosintat dari fotosintesis yang dilakukan oleh tanaman. Untuk melakukan fotosintesis tanaman memerlukan unsur hara, semakin banyak unsur hara yang diserap tanaman, hasil akumulasi fotosintat akan semakin besar. Berat kering merupakan penimbunan hasil bersih asimilasi $\mathrm{CO}_{2}$ yang dilakukan selama pertumbuhan dan perkembangan tanaman (Guritno dan Sitompul, 1995).

\section{Kadar Klorofil}

Berdasarkan uji BNT 5\% perlakuan $\mathrm{K}$ (kontrol) tidak berbeda nyata dengan perlakuan P1, P2 dan P3.

Tabel 3. Rata-rata klorofil total tanaman sawi hijau

\begin{tabular}{ll}
\hline Perlakuan & Klorofil (gr) \pm SetDv \\
\hline K & $0,127 \pm 0,0126^{\mathrm{a}}$ \\
P1 & $0,110 \pm 0,0115^{\mathrm{a}}$ \\
P2 & $0,122 \pm 0,0270^{\mathrm{a}}$ \\
P3 & $0,122 \pm 0,0237^{\mathrm{a}}$ \\
\hline Keterangan : & K1(kontrol) : Tanah, P1 : Arang \\
& Sekam 50\% + Tanah 25\% \\
& + Cocopeat 25\%, P2 : Arang \\
& Sekam 25\% +Tanah 25 \%+ \\
& Cocopeat $50 \%$, P3: Arang Sekam \\
& 25\% + Tanah 50\% + Cocopeat \\
& $25 \%$.
\end{tabular}

Hasil dari penelitian pada Tabel 3 di atas menunjukkan nilai tertinggi ada di setiap perlakuan. Hasil pengamatan terhadap pengukuran kadar klorofil pada bagian daun, batang/tangkai tanaman sawi hijau yang ditanam selama 1 bulan penanaman menunjukkan bahwa adanya perbedaan 
jumlah klorofil yang terkandung pada bagian daun, batang/ tangkai tanaman tersebut.

Faktor yang mempengaruhi kandungan klorofil pada suatu tanaman adalah umur tanaman, morfologi daun serta faktor genetik. Umur daun dan tahapan fisiologis suatu tanaman merupakan faktor yang menentukan kandungan klorofil. Tiap spesies dengan umur yang sama memiliki kandungan kimia yang berlainan dengan jumlah genom yang berlainan pula. Hal ini mengakibatkan metabolisme yang terjadi juga berlainan terkait dengan jumlah substrat maupun enzim metabolismenya (Setiari, 2009).

\section{KESIMPULAN}

Dari hasil penelitian yang telah dilakukan dapat disimpulkan bahwa pada perlakuan masing-masing kombinasi media tanam memberikan pengaruh yang tidak berbeda nyata dengan perlakuan lainnya. Selain itu penambahan arang sekam dan cocopeat ke dalam media tanam tidak berpengaruh terhadap pertumbuhan jumlah daun, berat segar dan berat kering.

\section{DAFTAR PUSTAKA}

Campbell, N.A., Reece, J.B., \& Mitchell, L.G. (2003). Biologi. Jilid 2. Edisi Kelima. Alih Bahasa: Wasmen. Jakarta: Penerbit Erlangga

ISTA International Rules for Seed Testing. (2006). Switzerland: The International Seed Testing Association. Bassersdorf.CH

Hidayah, H. N. dan A. Irawan. (2012). Kesesuaian Media Sapih terhadap Persentase Hidup Semai Jabon Merah (Anthocephalus macrophyllus (Roxb.) Havil). Balai
Penelitian Kehutanan Manado. Manado

Mulyana, D \& Ceng, Asmarahman. (2012). Untung Besar dari Bertanam Sengon. Jakarta: PT. Agro Media Pustaka

Oyetola, E.B., and M., Abdullahi. (2006). The Use of Rice Husk Ash in Low - Cost Sandcrate Block Production. Leonardo Electronic. Journal of Practices and Technologies. Issue 8: $58-70$

Rahman, A., Hermaya, dan Lisa. (2008). Pertumbuhan dan Produksi Tanaman Sawi Dengan Pemberian Bokash. Jurnal Agrisisten 4(2): 7580

Sarief, Saefudin. (1985). Kesuburan dan pupuk kandang Tanah Pertanian. Bandung: C.V Pustaka Buana

Setyorini, D., Soeparto., Sulaeman. (2003). Kadar logam berat dalam pupuk. Prosiding Seminar Nasional Peningkatan Kualitas Lingkungan dan Produk Pertanian. Badan Litbang Pertanian

Setiari N. (2009). Eksplorasi Kandungan Klorofil pada beberapa Sayuran Hijau sebagai Alternatif Bahan Dasar Food Supplement. BIOMA. Vol. 11, No. 1, Hal. 6-10

Sitompul S.M., \& Guritno Bambang. (1995). Analisis Pertumbuhan Tanaman. Yogyakarta: Gadjah Mada University Press.

Wijaya, K, A. (2008). Nutrisi Tanaman. Prestasi Pustaka. Jakarta. $115 \mathrm{hlm}$. 